\title{
ARTICLES
}

Submitted 04.18.2016. Approved 10.04.2016

Evaluated by double blind review process. Scientific Editor: Rafael Alcadipani

DOI: http://dx.doi.org/10.1590/So034-759020170205

\section{EDUCATING QUALITATIVE RESEARCHERS IN MANAGEMENT: TOWARD PERFORMATIVE JUDGEMENTS}

\author{
Educando pesquisadores qualitativos em administração para julgamentos \\ performativos
}

\author{
Educando investigadores cualitativos en administración para juicios \\ performativos
}

KEYWORDS | Qualitative research, doctoral management education, performative judgment, practical wisdom, sensible knowledge.

\section{RESUMO}

O objetivo deste ensaio é refletir criticamente sobre o ensino da pesquisa qualitativa nos cursos de doutorado em administração. A ideia central é oferecer uma proposta de educação em pesquisa qualitativa baseada no conceito de julgamento performativo. $O$ conceito de julgamento performativo está alicerçado nas virtudes intelectuais de Aristóteles por meio do conhecimento sensivel de Strati. A proposta busca um entendimento teórico da educação em pesquisa qualitativa, ao invés de descrever técnicas ou prescrições pedagógicas. A proposta educacional de julgamento performativo é, portanto, aberta e flexível, podendo se encaixar em diversos tipos de cursos de doutorado. Ela também ajuda a revelar as diferenças entre as ideias de treinamento e educação, apresentando como ambas podem ser utilizadas em conjunto em um processo educativo.

PALAVRAS-CHAVE | Pesquisa qualitativa, doutorado em administração, julgamento performativo, conhecimento prático, conhecimento sensivel.

\section{RESUMEN}

El propósito de este ensayo es reflexionar críticamente sobre la investigación cualitativa en la enseñanza de cursos de doctorado en la administración. La idea central es ofrecer una propuesta educativa en la investigación cualitativa basada en el concepto de juicio performativo. El concepto de juicio performativo tiene sus raíces en las virtudes intelectuales de Aristóteles y a través del conocimiento sensible del Strati. La propuesta busca una comprensión teórica de la educación en la investigación cualitativa, en lugar de describir los requisitos técnicos o educativos. La propuesta educativa del juicio performativo es, por tanto, abierto y flexible y puede adaptarse a diferentes tipos de programas de doctorado. También ayuda a revelar las diferencias entre las ideas de capacitación y educación, que muestra cómo ambos pueden ser utilizados juntos en un proceso educativo.

PALABRAS CLAVES I Investigación cualitativa, Doctorado en administración, Juicio performativo, Conocimiento práctico, Conocimiento sensibile.

\footnotetext{
MARCELO DE SOUZA BISPO

marcelodesouzabispo@gmail.com Professor at Universidade Federal da Paraíba, Programa de Pós- Graduação em Administração - João Pessoa - PB, Brazil
}

\begin{abstract}
The aim of this essay is to reflect critically on qualitative research education in doctoral management
programs. The central idea is to offer a qualitative research education model supported by the con-
cept of performative judgment. The notion of performative judgment draws upon Aristotle's virtues
of thought via Strati's idea of sensible knowledge. The proposal focuses on a theoretical understan-
ding of qualitative research education rather than prescribing pedagogical techniques or steps. The
performative judgment education model is therefore open-ended and flexible and may fit in different
doctoral program settings. It also helps to reveal the differences between the notions of training and
ABSTRACT
The aim of this essay is to reflect critically on qualitative research education in doctoral management
programs. The central idea is to offer a qualitative research education model supported by the con-
cept of performative judgment. The notion of performative judgment draws upon Aristotle's virtues
of thought via Strati's idea of sensible knowledge. The proposal focuses on a theoretical understan-
ding of qualitative research education rather than prescribing pedagogical techniques or steps. The
performative judgment education model is therefore open-ended and flexible and may fit in different
doctoral program settings. It also helps to reveal the differences between the notions of training and

ABSTRACT
The aim of this essay is to reflect critically on qualitative research education in doctoral management
programs. The central idea is to offer a qualitative research education model supported by the con-
cept of performative judgment. The notion of performative judgment draws upon Aristotle's virtues
of thought via Strati's idea of sensible knowledge. The proposal focuses on a theoretical understan-
ding of qualitative research education rather than prescribing pedagogical techniques or steps. The
performative judgment education model is therefore open-ended and flexible and may fit in different
doctoral program settings. It also helps to reveal the differences between the notions of training and

ABSTRACT
The aim of this essay is to reflect critically on qualitative research education in doctoral management
programs. The central idea is to offer a qualitative research education model supported by the con-
cept of performative judgment. The notion of performative judgment draws upon Aristotle's virtues
of thought via Strati's idea of sensible knowledge. The proposal focuses on a theoretical understan-
ding of qualitative research education rather than prescribing pedagogical techniques or steps. The
performative judgment education model is therefore open-ended and flexible and may fit in different
doctoral program settings. It also helps to reveal the differences between the notions of training and

ABSTRACT
The aim of this essay is to reflect critically on qualitative research education in doctoral management
programs. The central idea is to offer a qualitative research education model supported by the con-
cept of performative judgment. The notion of performative judgment draws upon Aristotle's virtues
of thought via Strati's idea of sensible knowledge. The proposal focuses on a theoretical understan-
ding of qualitative research education rather than prescribing pedagogical techniques or steps. The
performative judgment education model is therefore open-ended and flexible and may fit in different
doctoral program settings. It also helps to reveal the differences between the notions of training and

ABSTRACT
The aim of this essay is to reflect critically on qualitative research education in doctoral management
programs. The central idea is to offer a qualitative research education model supported by the con-
cept of performative judgment. The notion of performative judgment draws upon Aristotle's virtues
of thought via Strati's idea of sensible knowledge. The proposal focuses on a theoretical understan-
ding of qualitative research education rather than prescribing pedagogical techniques or steps. The
performative judgment education model is therefore open-ended and flexible and may fit in different
doctoral program settings. It also helps to reveal the differences between the notions of training and

ABSTRACT
The aim of this essay is to reflect critically on qualitative research education in doctoral management
programs. The central idea is to offer a qualitative research education model supported by the con-
cept of performative judgment. The notion of performative judgment draws upon Aristotle's virtues
of thought via Strati's idea of sensible knowledge. The proposal focuses on a theoretical understan-
ding of qualitative research education rather than prescribing pedagogical techniques or steps. The
performative judgment education model is therefore open-ended and flexible and may fit in different
doctoral program settings. It also helps to reveal the differences between the notions of training and

ABSTRACT
The aim of this essay is to reflect critically on qualitative research education in doctoral management
programs. The central idea is to offer a qualitative research education model supported by the con-
cept of performative judgment. The notion of performative judgment draws upon Aristotle's virtues
of thought via Strati's idea of sensible knowledge. The proposal focuses on a theoretical understan-
ding of qualitative research education rather than prescribing pedagogical techniques or steps. The
performative judgment education model is therefore open-ended and flexible and may fit in different
doctoral program settings. It also helps to reveal the differences between the notions of training and education, showing how they can work together in the educational process.
\end{abstract}




\section{INTRODUCTION}

Over the last two decades, management education-especially doctoral management education - has been given less attention than management and organizational research (Dent, 2002; French \& Grey, 1996; Vaara \& Fay, 2012). This situation reflects scholars' principal focus on research to the detriment of teaching and education, arising from the recognition that comes from publishing as opposed to classroom and other forms of education performance (Marx, Garcia, Butterfield, Kappen, e Baldwin , 2015).

According to Vaara and Fay (2012), we are living in a period of reproduction of management education-which includes doctoral education-at large scale. This situation has been caused in part by the spread of university accreditations and rankings that lead to homogenization in management You management education regardless of the context in which it happens.

One of these understandings is the idea of "publish or perish" that has increased the distance between research and teaching. This approach creates the sense that good universities should prioritize research over teaching. It has become common to find scholars working at universities who do not like teaching (Czarniawska, 2015; Marx et al., 2015).

Even assuming that the most prestigious universities are those where good research is pursued, it is not possible to deny that universities are also places of education, teaching, and learning. Seeing universities primarily as research spaces violates their nature (Cassuto, 2015).

Czarniawska (2015) discloses a situation to demonstrate carelessness with teaching. "Once when bemoaning a lack of interest from practitioners in front of a US audience, I met with the response that there was nothing to worry about: After all, there are so many doctoral students to teach!” (p. 111). This statement points toward a typical but worrying situation. It is worrying because doctoral education has problems (Cassuto, 2015; Dent, 2002; Marx et al., 2015). One of them is the lack of identity regarding doctoral programs' goals and ends (Association to Advance Collegiate Schools of Business-AACSB, 2013; Banerje \& Moreley, 2013; Khurana \& Spender, 2012; Marx et al., 2015; Mowbray \& Halse, 2010). For Khurana and Spender (2012), "business schools doctoral programmes are unclear about their purpose and vision" (p. 635), while for Marx et al. (2015) "business doctoral programs are something of an enigma" (p. 3). Another problem is the lack of adequate follow-up and feedback to doctoral students by professors saying that doctoral education is a self-learning process of "on the job" and "hands-on," thus justifying the diminished attention to teaching (Marx et al., 2015).
Another common issue is an imbalance between quantitative and qualitative research teaching and education. In many doctoral management programs, especially in the US, qualitative research does not receive the same attention that quantitative research does. This situation affects both the quality of qualitative research and the peer-reviewing of such research. Examples of poor peer-reviewing quality are questions posed by reviewers about a) the small number of interviews the researcher carried out; b) problems of sampling; and c) queries about data reliability made from a quantitative perspective. Another typical problem is authors pointing out that their studies have limited validity because it is impossible to generalize qualitative findings (Creswell, 2013; Stake, 2010).

These problems are partly due to poor qualitative research education in doctoral programs and a misunderstanding of the differences between education and training. Education presupposes learning and involves knowledge and understanding, whereas training involves only the mastery of a narrow set of skills (Thomas \& Anthony, 1996).

The aim of the present essay is to reflect critically on qualitative research education in doctoral management programs. The central idea is to offer a qualitative research education model supported by the concept of performative judgments. The notion of performative judgments draws upon the relationships between theory and practice as well as training and education. It is theoretically supported by a practice perspective (Antonacopoulou, 2015; Bourdieu, 1990; Schatzki, 2001) departing from a rereading of Aristotle's virtues of thought (Aristotle, 1999; Pakaluk, 2005) and Strati's idea of sensible knowledge (Strati, 2007). Performative judgments are the ongoing ability of make decisions and solve complex problems.

Although Aristotle's virtues of thought influence the proposed qualitative research education model, the notion of science (episteme) adopted in this essay differs from the Aristotelian idea of universal, timeless, and unchanging knowledge. Science here draws on time-dependent, changing paradigms and the application of epistemic values by scientists (Kuhn, 1996/1962). In this sense, science "require[s] practical judgement alongside skill and craft" (Christie, 2012, p. 104) and covers a potentially vast array of sets of practices, each informed by what can be called a particular epistemic community (Kinsella $\&$ Whiteford, 2009). Thus, research is seen as an embodied and situated scientific practice (Christie, 2012; Macklin \& Whiteford, 2012; Schatzki, 2012) wherein "practice" is a set of activities originated from the nexus of sayings and doings (Schatzki, 2001).

This essay aims to provide an understanding of effective qualitative research education rather than to prescribe pedagogical 
techniques or steps. According to Macklin and Whiteford (2012), "qualitative research requires instruction in the practice of practical judgement as opposed to the technical training required for quantitative research" (p. 88). The qualitative researcher needs the "ability to adjust to the changing circumstances of a situation and a capacity to combine knowledge, judgement, understanding, emotion, and intuition to act appropriately" (Macklin \& Whiteford, 2012, p. 93).

The notion of performative judgment is open-ended and flexible and may fit within different doctoral program settings. It also helps to clarify differences between training and education and how they can work together in the educational process. Performative judgments lead doctoral students towards emancipation (Freire, 1970) in the practice of qualitative research. They help them understand the difference between rigor and rigidity and avoid "methodological jails" in which methods drive research. Performative judgments also stimulate doctoral students to be critical and creative, enabling them to be in charge of the research process without replicating “cake recipes" or attempting to fit their research under a specific methodological label. In other words,

Instead of rigorously following a set of received rules, researchers would need to examine their own doings continuously. Asked, "Why do you do this that way?" they would be forbidden to answer, "Because this is how it is being done in my discipline," followed by parentheses filled with names and dates. They would have to argue for the approach chosen, for the techniques selected, for the format of the report produced. (Czarniawska, 2016, p. 3)

The next topic discusses training and educating and considers the significance of this difference for qualitative research education. Next, the theoretical notion of performative judgment is introduced, drawing on the ideas of practice focusing the virtues of thought and sensible knowledge. Subsequently, the discussion turns to the elements of qualitative research that drive doctoral students toward performative judgments.

\section{TRAINING, EDUCATION, AND IMPLICATIONS FOR QUALITATIVE RESEARCH TEACHING}

Many universities around the world offer doctoral management education. Despite the wide range of doctoral management programs, debates on teaching in doctoral education are still incipient (Banerje \& Moreley, 2013; Khurana \& Spender, 2012; Marx et al., 2015; Mowbray \& Halse, 2010). Discussions about teaching at the graduate level are important given the need to improve students' knowledge and skills in research and teaching. The small number of studies and debates about teaching in doctoral management education has relevant implications for teaching and researching practices.

The mainstream scholarly idea that doctoral management courses should educate people to be researchers, even though the majority of these students will look for and find positions as professors who teach (Marx et al., 2015), creates a misunderstanding of the relationship between teaching and researching. Currently, it is not possible to state that all distinguished researchers are also good teachers, even if they are working at a university and have the responsibility to prepare future professionals (Khurana \& Spender, 2012; Marx et al., 2015). In addition, if a person is an excellent researcher but not an excellent teacher, his/her doctoral students will probably not reach their professor's excellence in research because a good researcher might not mean the same as a good teacher. This discrepancy between research and teaching excellence also means that the quality of research of future researchers will be compromised owing to doctoral education failure. It is important to notice that the criticism here is aimed at the professor's role during the doctoral student's education process and does not assume that learning is limited to what Freire (1970) calls "banking education" but applies to the professor-student relationship as well.

Two questions that guide this discussion are 1) where and how do professors learn to teach doctoral students? 2) Are doctoral and undergraduate teaching similar? If the likely answer to these questions is "in practice"; it is possible to guess that teaching at the doctoral level has not been adequately conceived due to a lack of understanding of what doctoral education is, and the failure may affect the research achievements of future researchers. Another important debate concerns the way professors train and educate doctoral students (Dent, 2002). Using the words "training" and "education" interchangeably has considerable implications for the way that students are prepared for their future careers.

According to Thomas and Anthony (1996) "education also implies that the learner changes as a result of the learning experience; education is that which alters the learner's way of being" (p. 22). In this context, it is important to understand that qualitative research education cannot be reduced only to training in methods, but rather reaches for research mastery and thus emancipation and autonomy (Freire, 1970). Even though 
some training activities for qualitative research are important and needed (for example, coding qualitative data), they are not educational.

"Education" here encompasses those activities that promise students emancipation by forming them to carry out research masterly in a critical and creative manner. It creates the possibility for them to think out of the box and to recognize the difference between rigor and rigidity using "self-reflection" (Czarniawska, 2016). Faculty members have to educate students not just to employ techniques and methods rigidly. It is desirable to educate them towards emancipation through self-reflection to enable them to make right decisions that are supported by a comprehensive understanding of knowledge, the limitations of science, and how to access different sorts of phenomena with accurate methods and techniques.

Training is part of education; it conveys particular skills that help the researcher carry out research under specific conditions. It involves, for example, showing doctoral students how to use a piece of software or how to write or review a paper. But it does not show them how to create new knowledge and to be creative. The word "training" also has a narrow function related to certain technical and rule-oriented parts of research such as data analysis and findings report. Hence, training presupposes a tool that has a precise usage and does not enable doctoral students to solve complex problems.

Thinking that training and education are the same may lead to the confusion of rigor and rigidity. Skills developed as tools for specific uses become ends in themselves, and the "right" application of these tools claims scientific rigor when, in truth, it is only rigidity linked to that skill. When doctoral students learn to use methods strictly, they learn that scientific rigor is the accomplishment of those methods according to rules. However, methods are tools to be used according to research goals and not only according to rules.

What, then, is seen as "rigorous scientific conduct"-not in philosophy but in the practice of science? Mostly, it is understood as following to the letter a set of rules imposed by (some) scientists on other (usually younger) scientists and sometimes even on themselves. Deviations are seen as flaws in self-discipline, as poor professionalism, as incompetence. Yet, as Kuhn (1996 [1962]) made explicit many years ago, all scientific revolutions depend on deviations from and/or breaking these rules. (Czarniawska, 2016, p. 3)
Rigor as “self-reflection” (to use Czarniawska's term) involves applying the appropriate research tools supported by epistemological and theoretical understanding to achieve the stated objectives of the investigation.

It is desirable to educate doctoral students to understand how to reach research goals using whatever available methods are appropriate or creating new ones. They should not pick a research method and simply use it according to of its "rules." Put another way, the research goal should drive the method and not the opposite. Unfortunately, when doctoral students are only trained on methods, they focus on methods' rules and do not learn to think methodologically, to combine them, or to create new ones. Hence, an education process is needed in which doctoral students can learn to choose different methods in the light of their research goals and subject matter, aiming to justify their choices and to recognize the methods' limitations. Below are examples of questions that cannot be answered by those merely trained to replicate methods:

- Is it necessary to transcribe all interviews in qualitative research? Why do researchers usually transcribe interviews?

- How many interviews are necessary to carry out qualitative research?

- Is it possible to conduct qualitative research without interviews?

- Is it possible to generalize data from qualitative research?

These questions are common to doctoral students, and many scholars are not able to answer them appropriately due to their lack of knowledge about the principles of qualitative research. This is especially true of question one, simply because some scholars automatically reproduce transcribing procedures as taken-for-granted without reflecting on them. This is an example that evinces the need for education to stimulate critical thinking and mastery.

Qualitative research mastery also involves the researcher's capacity to judge appropriately how to design research and grasp the nature of his/her data. This involves adequately identifying and employing a set of techniques and field strategies to reach the research goal. Judgment is in this sense a performative action (Antonacopoulou, 2015) of employing sensible knowledge to understand the research setting and to make the good decisions. It plays a role throughout the research process, from the research design to the findings report. 


\section{PERFORMATIVE JUDGMENTS: VIRTUES OF THOUGHT AND SENSIBLE KNOWLEDGE}

Subjectivity is part of qualitative research studies, and its features help researchers to find explanations and create knowledge about how certain sorts of phenomena happen (Creswell, 2013; Stake, 2010). Different from the quantitative scholar, the qualitative researcher does not seek exact parameters to explain phenomena and create knowledge but instead performs the role of interpreter of people and their social and organizational settings (Stake, 2010). The interpreter has the ability to analyze research data, giving meaning to it with rigor. The interpretation process requires dexterity to make judgments about the field of study, the object, the research process, and reporting the findings. Qualitative research learning goes beyond acquiring techniques; it requires learning how to make practical judgments (Antonacopoulou, 2015; Bourdieu, 1990; Shotter \& Tsoukas, 2014). "Qualitative research requires instruction in the practice of practical judgement as opposed to the technical training required for quantitative research" (Macklin \& Whiteford, 2012, p. 88).

By "judgement," I mean the researcher's capacity for "knowing-in-action" supported by "theories-in-use” (Schön, 1987), which promotes a kind of "embodied reflection" (Kinsella, 2012). Bourdieu (1990) holds that

judgement regards to the 'system of preferences' which underlies it, depend not only on all the previous choices of the decider but also on the conditions in which his 'choices' have been made, which include all the choices of those who have chosen for him, in his place, pre-judging his judgements and so shaping his judgment. (pp. 49-50)

For Kinsella (2012)

illuminating the implicit criteria by which practitioners make judgements may be a useful way both to conceive of, and make explicit, the balancing act in which professionals continually engage, and to begin to think about what types of considerations might lead practitioners beyond instrumental approaches and toward practical wisdom in their interpretations and judgements in practice. (p. 47)

Aristotle (1999) advocates the notion of practical wisdom (from the Greek word phronesis) for desirable good judgment, while Strati (2007) claims that aesthetics and sensible knowledge are needed to perform judgments. What I claim as "performative judgment" is the ability to make good decisions within a research practice field (Bourdieu, 1990). It requires the interplay of Aristotle's virtues of thought supported by the sensible knowledge (Strati, 2007).

\section{Virtues of thought}

Aristotle's "virtues of thought" are composed of "practical wisdom or administrative ability-phronesis," "scientific knowledgeepisteme," "craft knowledge-techne," "understanding-nous," and "wisdom-sophia." This set of virtues is interrelated and obeys a certain hierarchy (Pakaluk, 2005). Exhibit 1 provides a summary of each virtue.

Pakaluk (2005) points out a subordination among these virtues and explains that

Craftsmanship is subordinated to administrative ability, on the grounds that the latter deals with acting well, and the former with making things well, and generally we make things as instruments of action: doing [practical judgement] is prior to making [hands-on]. But administrative ability is subordinated to knowledge on the grounds that the former aims to bring about something, relative to our interests and needs, but the latter need not aim for any result beyond itself, and it can be concerned with matters that are not relative to or restricted to our interests. Yet knowledge is subordinated to wisdom, on the grounds that, in aiming to know anything at all, we thereby aim above all to know the most basic causes and reasons of things, and this is what wisdom is directed at (my emphasis). (p. 207)

It is important to notice that for Aristotle, practical wisdom (or administrative ability) is what coordinates and mediates the other intellectual virtues (Cummings \& Tsoukas, 1997; Shotter \& Tsoukas, 2014) due to its job of guiding good decisions. Cummings and Tsoukas (1997) state "it is the ability to see the common good and put it in practice" (p. 6), an effort to act with political sagacity and practical intelligence.

Another important aspect of Aristotle's scheme is that both practical wisdom and craft knowledge are kinds of practical knowledge, whereas scientific knowledge and understanding are theoretical. Wisdom is also theoretical and is the combination of scientific knowledge and understanding. Thus, what I call "performative judgment" involves the interplay of all five virtues of thought supported by sensible knowledge. 


\section{Exhibit 1. Aristotle's five virtues of thought}

\begin{tabular}{|c|c|}
\hline Virtue & Description \\
\hline $\begin{array}{l}\text { Scientific } \\
\text { knowledge }\end{array}$ & $\begin{array}{l}\text { "What we know scientifically does not even admit of being otherwise, and whenever what admits of being otherwise escapes } \\
\text { observation, we do not notice whether it is or is not. Hence, what is known scientifically is by necessity" (Aristotle, } 1139 \mathrm{~b} 2 \text { ). } \\
\text { It is deduction supported by basic principles. }\end{array}$ \\
\hline $\begin{array}{l}\text { Craft } \\
\text { knowledge }\end{array}$ & $\begin{array}{l}\text { Craft knowledge is concerned with coming to be, and "the exercise of the craft is the study of how something that admits of } \\
\text { being and not being comes to be, something whose principle is in the producer and not in the product." (Aristotle, 1140a 4). } \\
\text { Craft knowledge pretense to building things. }\end{array}$ \\
\hline $\begin{array}{l}\text { Practical } \\
\text { wisdom }\end{array}$ & $\begin{array}{l}\text { Practical wisdom is about human concerns, about things open to deliberation. "For we say that deliberating well is the } \\
\text { function of the prudent person more than anyone else; but no one deliberates about things that cannot be otherwise, or } \\
\text { about things lacking any goal that is a good achievable in action" (Aristotle, 1141b 6). Practical wisdom is deliberating } \\
\text { according to human beings' common sense of what is good or bad. }\end{array}$ \\
\hline Understanding & $\begin{array}{l}\text { Understanding has "grasped the truth and never make mistakes, about what can or cannot be otherwise, it means that we } \\
\text { have understanding of principles. Neither scientific knowledge, practical wisdom, and wisdom is possible about principles" } \\
(\text { Aristotle, } 1141 \mathrm{a} 2 \text { ). }\end{array}$ \\
\hline Wisdom & $\begin{array}{l}\text { "The wise person must not only know what is derived from the principles of science but also grasp the truth about the } \\
\text { principles. Therefore, wisdom is understanding plus scientific knowledge; it is scientific knowledge of the most honorable } \\
\text { things that has received its coping stone" (Aristotle, } 1141 \mathrm{a} 3 \text { ). }\end{array}$ \\
\hline
\end{tabular}

Source: Adapted from Aristotle (1999).

\section{Sensible knowledge}

Aristotle's notion of judgment is centered on practical wisdom. However, another important aspect of judgment encompasses the human senses. Aristotle (1999) assumes the relevance of the senses to what he calls "perception of particulars," a kind of knowledge created by the senses. However, he does not consider the knowledge that emerges from the senses as part of the virtues of thought. Aristotle considers the senses as only "perceiving" without in-depth explanation.

Over the last three decades, aesthetics (and the human senses) have become a matter for many scholars producing scientific knowledge in organization studies and management education (Strati, 1992, 2007; Sutherland, 2012; Warren, 2008). According to Strati (2007)

Even though it extends back through philosophical, religious and political-social theory until antiquity, sensible knowledge took shape as an independent notion in the seventeenth and eighteenth centuries. It was only then, in fact, that sensible knowledge became a subject of the modern disciplines following the advent of aesthetic philosophy (BAUMGARTEN, 1735/1954, 1750-58/1986; VICO, 1725), a social practice which instituted, framed, enabled and definitively qualified the social experience of art, and more generally of studies of society. (p. 64)
Bourdieu (1990) advocates the relevance of a "practical sense" and the key role that the sensible plays to perform and understand practice. In his words,

Practical sense, social necessity turned into nature, converted into motor schemes and body automatisms, is what causes practices, in and through what makes them obscure to the eyes of their producers, to be sensible, that is, informed by a common sense. It is because agents never know completely what they are doing that what they do has more sense than they know. (p. 69)

The idea of sensible knowledge assumes that the body is not subordinated to the mind-as proposed by Aristotle-and that the mind is embodied (Merleau-Ponty, 2004; Strati, 2007). Sensible knowledge derives from the senses and draws on the "corporeal relation with the experience of the world" (Strati, 2007, p. 62). It is also a continuous interaction between the individual and the Other (human or non-human).

Sensible knowledge concerns what is perceived through the senses, judged through the senses, and produced and reproduced through the senses. It resides in the visual, the auditory, the olfactory, the gustatory, the touchable and in the sensitive-aesthetic judgement. It generates dialectical relations with action and close relations with the emotions of organizational actors. (Strati, 2007, p. 62) 
Qualitative research practice involves sensible knowledge when, for instance, the researcher has to interpret gesture, tone of voice, and feelings to describe people and situations as good, bad, happy, angry, sad, excited, etc. When describing whether a person is happy or sad about something, it is through the sensible knowledge that the researcher learns it. The senses are responsible not only for offering the researcher access to data, but also for supporting his/her analysis, interpretations, and decisions. For example, researchers that use discourse analysis can only employ this method when they are able to interpret speech and its underlying elements. This is something the researcher accomplishes through his/her senses and the sensible knowledgepractical sense. The challenge for qualitative research professors is how to educate students to know and employ sensible knowledge during the research process to support their judgments.

According to Griffiths and Mack (2011) "with the domination of the visual, aesthetic researchers often face challenges with the evocation and representation of multiple sensory experiences and multiple aesthetic judgements" (p. 736). Strati (2007) points out that sensible knowledge "is a form of knowing-and actingprofoundly diverse from the knowledge gathered and provided through the logical and ratiocinative cognitive faculty directed towards 'intelligible' worlds” (p. 62). In this sense, Warren (2008) draws attention to the need for understanding the impact of sensory knowledge on methodological procedures in organization and management research.

\section{Performative judgment model}

Qualitative research education needs to enable doctoral students to make performative judgments. It implies intellectual autonomy to replicate theories and methods, to put them to new uses, to revise them, or to improve new ones in dealing with research complexity. Figure 1 illustrates the dynamics of how intellectual virtues and sensible knowledge can drive performative judgments.

Figure 1. Performative judgments

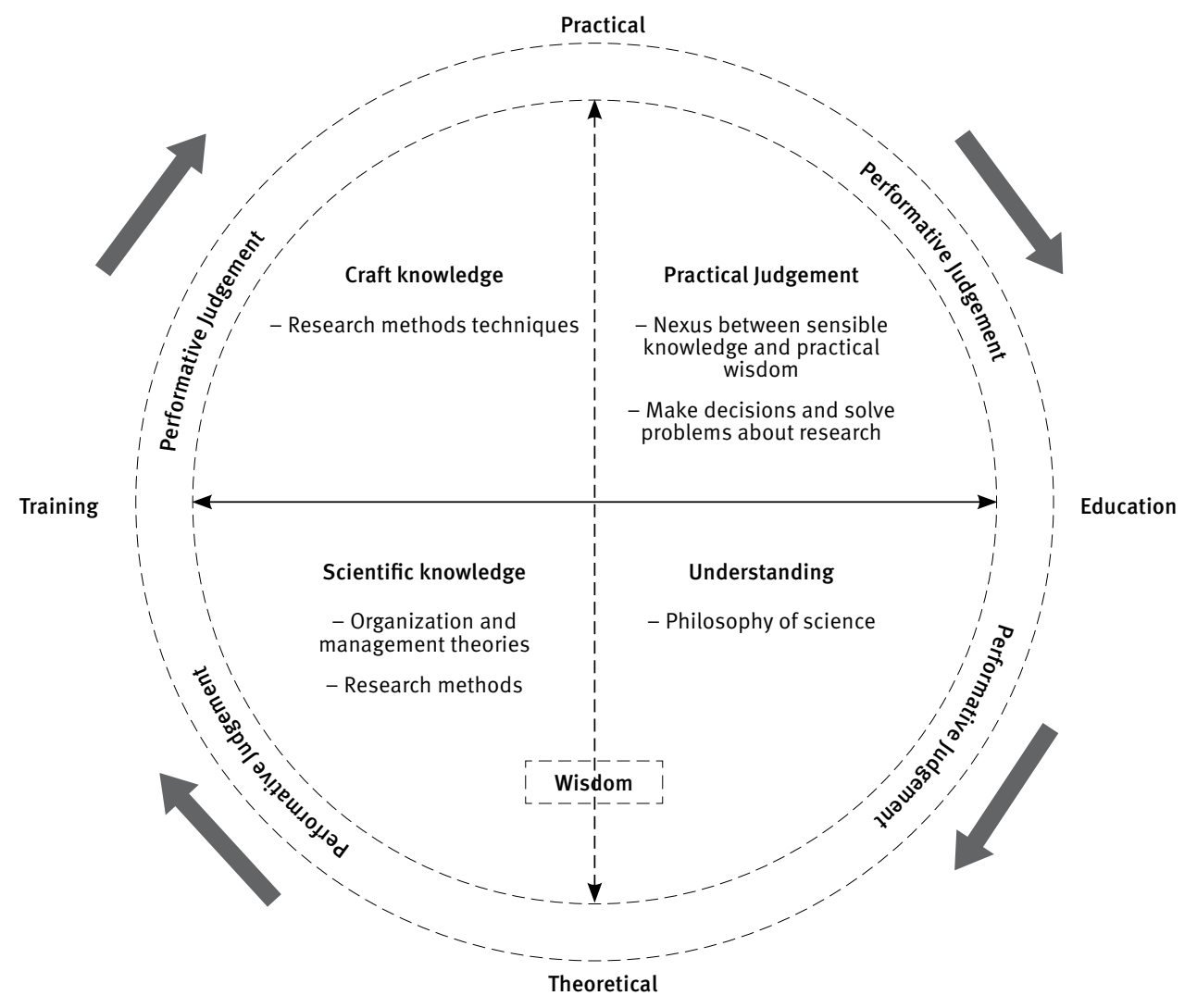


The interplay of the continuums between training and education as well as the theoretical and the practical create a dynamic process towards performative judgments. According to this understanding, performative judgment is a practice (Schatzki, 2001) that encompasses aspects of training as well as education. In doing so, it is possible to deal with complex problems concerning research design and research accomplishment, such as data access, data analysis and interpretation, and data reporting.

It is important to notice that both training and education are interrelated and have theoretical and practical aspects. I understand that scientific knowledge and craft knowledge are matters of training, whereas understanding and practical wisdom are matters of education. Performative judgments are useful to help qualitative researchers be prepared to carry out research with autonomy and not simply to replicate knowledge and methods.

\section{TAILORING QUALITATIVE RESEARCHERS' EDUCATION TOWARD PERFORMATIVE JUDGMENTS}

For doctoral students to attain performative judgment, doctoral programs need to reflect on how to reach this goal. Performative judgment leads doctoral students to emancipation. The concept of emancipation adopted here draws upon Paulo Freire's (1970) understanding of education.

According to Freire (1970), education is a process whereby individuals come to be able to participate actively in society and think critically about the world. Freire was critical of traditional pedagogical strategies based only on acquiring and memorizing contents; he calls these strategies "banking education" (Freire, 1970). Banking education is the understanding that knowledge is a process of accumulating contents, and its teaching involves lectures to be memorized in order to achieve good grades in tests. Freire's central assumption is that individuals have to be educated in order to act critically in the world and not simply replicate knowledge that sometimes seems useless.

Regarding qualitative research education, Freire's ideas (1970) about emancipation are helpful in reflecting on the research mastery of doctoral students. Emancipation supports abandoning qualitative research banking education (focused only on replicating methods) towards an education process aiming at fostering performative judgments-an ability to be creative and make good decisions in different research settings.
To achieve this, it is necessary to combine theoretical and practical aspects of training and education-figure 1. Achieving mastery via performative judgments requires special attention to educational elements of theory (philosophy of science and scientific knowledge-episteme) and practice (craft knowledge and practical judgment).

\section{Theoretical aspects of judgment}

On the theoretical side, philosophy of science is useful to help doctoral students understand the different kinds of knowledge (the principles) beyond what is usually called "scientific knowledge." It also introduces the epistemological and paradigmatic struggles that occur in science practice (Chishtie, 2012; Czarniawska, 2016; Kuhn, 1996/1962). The core idea is not to educate management doctoral students to be philosophers but to make them aware of the complexities and controversies involved in doing science. Understanding the complexities of science and the existence of different ontological and epistemological positions enables doctoral students to question and analyze the assumptions of current organization and management theories. It is also useful for designing qualitative research and making coherent ontological, epistemological, theoretical, and methodological choices.

Usually, scholars' doubts and questions about the practice of qualitative research emerge from a lack of ontological and epistemological understanding or misunderstandings of these topics. Philosophy of science is the starting point of qualitative research education due to its capacity to offer critical thinking about the research practice, while organization and management theories, as well as research methods, are the means. Teaching qualitative research simply as a set of research methods shows these tools to students in a limited range of their use. Students will probably take this narrow understanding as the only truth for carrying out research, trying to replicate and "fit" their research into a method. Teaching as mere training leads students to replication and does not offer them the possibility of critical thinking about knowledge creation and opportunities for creativity that an education process does.

Rather than simply teaching the variety of research methods, it is crucial to discuss with doctoral students the extension of qualitative data that each technique can gather and the underlying assumptions in this process. The main questions are "What sort of data can I catch through interviewing, observing, and analyzing documents? How can I choose and combine these techniques according to my research goals, time and resources?" From this kind of discernment, it will become easier to learn research 
methods and their core assumptions, opening the possibility of employing, modifying, or combining methods.

This education regarding the philosophy of science is relatively straightforward to accomplish due to its theoretical character. According to Aristotle (1139b) “[...] every science seems to be teachable, and what is scientifically knowable is learnable." Therefore, adopting the philosophy of science as part of the doctoral curriculum is a simply matter of introducing its elements as a separate course itself or as part of research methods courses.

\section{Practical aspects of judgment}

By contrast, the practical part of qualitative research education cannot be developed only inside classrooms. It is composed of craft knowledge and practical judgment (see figure 1). Craft knowledge involves training-hands-on-about research methods and techniques. The practical judgment about how to employ those methods is supported by the nexus between practical wisdom (phronesis) and sensible knowledge.

Craft knowledge needs training aspects beyond classroom teaching; it is necessary to be "out-there" experiencing how to deal with different sorts of techniques such as observing and interviewing. Through practical exercises to live research, it is possible to understand the potentialities and limits of methods and techniques and to acquire the practical sense of research (Bourdieu, 1990). This experience is required because practical judgment is something intrinsic, not teachable through traditional tools (Kinsella, 2012; Macklin \& Whiteford, 2012; Shotter \& Tsoukas, 2014; Strati, 2007). The development of practical judgment involves engagement in the research practice with professors and/or senior researchers mentoring. The process of mentoring is responsible for guiding doctoral students during the process of making difficult decisions by sharing experiences and offering feedback. The development of practical judgments draws on the notion of theories-in-use (Schön, 1987).

\section{Performative judgment and the qualitative research education model}

Performative judgment is the complex interplay between theoretical and practical aspects of the model, involving moments of training and education. Performative judgment is an ongoing practice to support making decisions and solving complex problems. Regarding qualitative research, performative judgment is a concept that helps both professors and doctoral students to understand the dynamics of research and how to figure out ways of improving future researchers' education. For Macklin and Whiteford (2012) qualitative research and its forms of education should be interrelated.

Our arguments also hold implications for the teaching of qualitative research drawn from the recognition that such research follows a form or wisdom or rationality different from quantitative methods. In discussion of the philosophical underpinnings of research, for example, we suggest that rather than teach students a narrow scientific view of social science, they should be thoroughly introduced to the varieties of wisdom and reasoning that exist and that a clear association be drawn between practical wisdom and qualitative research. Students should be made aware that if they wish to become 'professional' qualitative researchers, they need to develop their practical reasoning skills, which, it can be argued, will not be achieved through the learning of correct procedures or formulae but through reflecting on their already developing practical wisdom and through ongoing practice and experience. (p. 98)

The key point to use the performative judgment concept to prepare qualitative researchers rests on the necessity of aligning qualitative research education with the philosophical assumptions of qualitative research. Prepar future qualitative researchers supported only by training aspects or just working inside classrooms reading articles is a form of education based on a "step-by-step" rationality that differs from the qualitative research practice that is situated, engaged, and embodied. At the same time, the qualitative research education model recognizes and encompasses the necessity of using theoretical and practical aspects that involve the research process. This understanding departs from the idea that knowledge creation is always an ongoing practice that requires moments of theorizing and abstraction as well as hands-on and practical sense. Figure 2 illustrates the qualitative research education model.

It is important to notice that the proposal is dynamically integrated and uses dashed lines to highlight the possibility to employ it in a flexible way without rigid boundaries determining definitive rules. The qualitative research education model is a conceptual proposal that can be used in many different doctoral programs. It is an educational proposal, not a course design. 
Figure 2. Qualitative research education model based on performative judgments

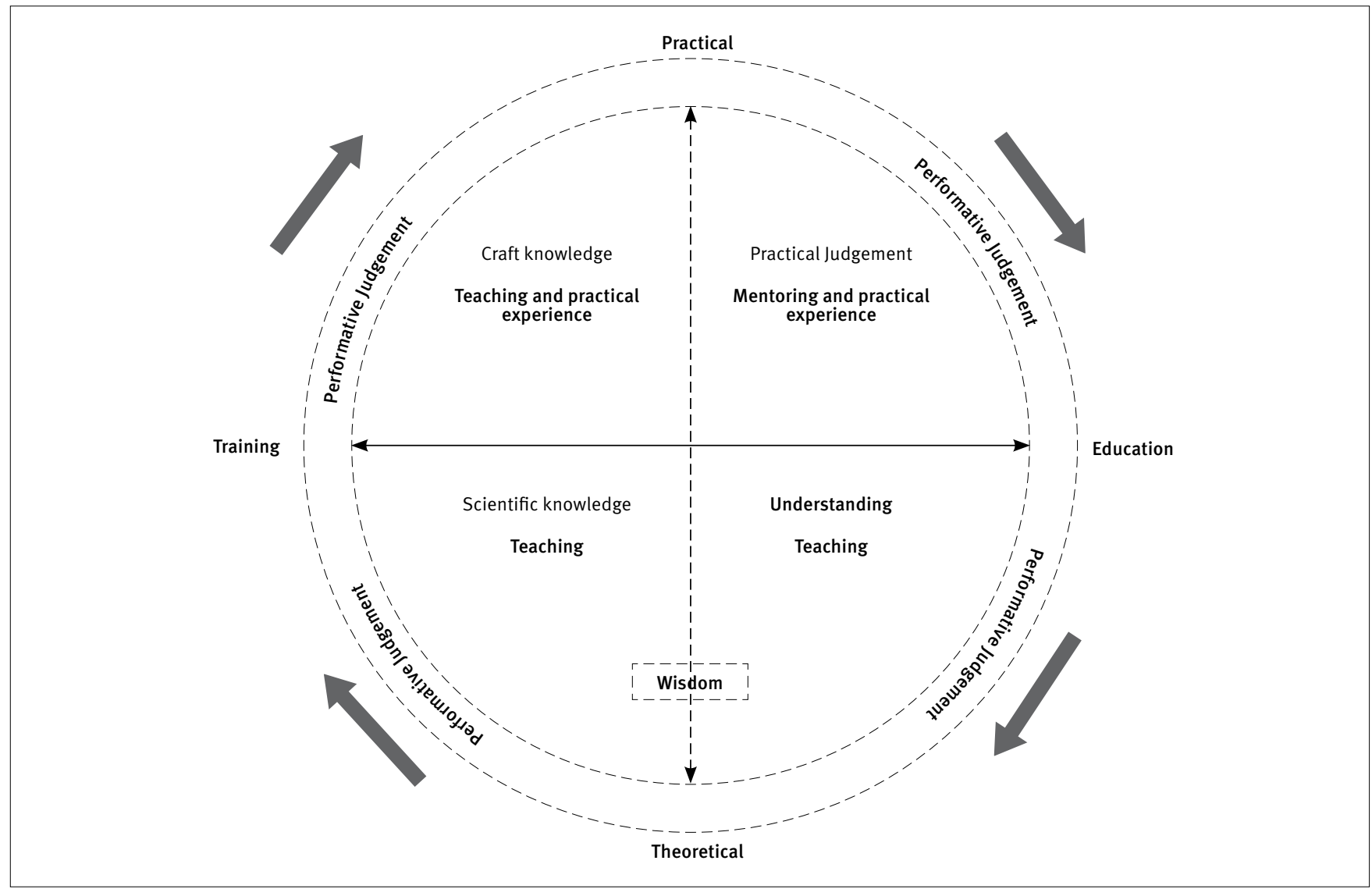

\section{Final remarks}

The aim of this essay was to reflect critically on qualitative research education in doctoral management programs, offering a model based on the concept of performative judgment. The discussion reflects three states of affairs, 1) the debate and research about doctoral management education, 2) carelessness at universities about teaching strategies at the doctoral level, and 3) the need to educate qualitative researchers toward emancipation instead of only replication.

Regarding qualitative research practice, the lack of welldefined conceptions of education to educate future researchers leads to problems with research design, data analysis, and finding reports, as well as with the quality of peer-reviewing. Even though many scholars agree that doctoral education is an on-the-job and hands-on process, this experiential strategy has to be supported by professors' follow-up and feedback, and an educational concept as well.

My proposal is that qualitative researchers shall be educated towards autonomy by acquiring the ability to make performative judgments in pursuit of qualitative research mastery. The performative judgment could be useful due to the nature of qualitative research that includes demands on how to deal with subjective issues and different sorts of data. It is not enough simply to know research methods without the capacity to understand the context, the subject, and the research field setting. It is also necessary to understand how different techniques and methods can be used to analyze and interpret organizational phenomena.

The qualitative researcher does not analyze data exclusively by well-established criteria; rather he/she acts as interpreter. This situation demands from the qualitative researcher the capacity to make good decisions supported by his/her experience in the field and oriented by ontological, epistemological, and theoretical understanding (rigor); data do not say anything except through researchers' coherent interpretations. For this reason, training alone cannot give doctoral students the ability for performative judgment; a whole education process is also needed. This involves educating people to deal with research complexity and to act creatively, avoiding methodological jails and rigidity.

This essay has five principal contributions. First, it enlivens the debate on teaching in doctoral education. Second, it highlights the need for a clear concept of education to prepare future qualitative researchers. Third, it clearly differentiates 
between "training" and "education." Fourth, it offers a theoretical model for qualitative research education. Fifth, performative judgment is not only to be used in research but is also helpful to understand forms of organizing and how people make decisions within organizational settings. Performative judgment differs from the "rational reasoning" and draws on a "practical reasoning," looking for understanding organizational dynamics instead of prescribing "correct" solutions. However, some points remain to be developed, including how to fit qualitative research into the doctoral curriculum and how many hours, credits, or courses are needed to realize this model. Another issue is the dialogue between qualitative and quantitative research, aimed at developing an integrated research education.

\section{Note of acknowledgement}

I would like to thank Coordination for the Improvement of Higher Education Personnel (Coordenação de Aperfeiçoamento de Pessoal de Nivel Superior [CAPES]) for the financial support of this research, Professor Ted Schatzki (University of Kentucky) for his valuable contributions in the early stages of this paper, professor David Bradshaw (University of Kentucky) for the tips about Aristotle's work, and the reviewers and associate editor for their significant contributions during the blindreview process.

\section{REFERENCES}

Association to Advance Collegiate Schools of Business-AACSB . (2013). The promise of business doctoral education: Setting the pace for innovation, sustainability, relevance, and quality. Retrieved from http://www.aacsb.edu/ /media/AACSB/Publications/research-reports/the-promise-of-business-doctoral-education.ashx

Antonacopoulou, E. (2015). One more time: What is practice? Teoria e Prática em Administração - TPA, 5(2), 1-26.

Aristotle. (1999). Nicomachean ethics (2nd ed., Terence Irwin, Trans.). Indianapolis, USA: Hackett Publishing.

Banerje, S., \& Moreley, C. (2013). Professional doctorate in management: Toward a practice-based approach to doctoral education. Academy of Management Learning \& Education, 12(2), 173-193. doi: 10.5465/amle.2012.0159

Baumgarten, A. G. (1735). Meditationes philosophicae de nonnullis ad poema pertinentibus. Halle in Magdeburgo: Grunert. [English trans., Reflections on Poetry, ed. K. Ashenbrenner and W. B. Holter. Berkeley, CA: University of California Press, 1954.].

Baumgarten, A. G. (1750-58). Aesthetica. Kleyb: Frankfurt am Oder(photostat, Olms: Hildesheim, 1986).
Bourdieu, P. (1990). The logic of practice. California, USA: Stanford University Press.

Cassuto, L. (2015). The graduate school mess: What caused it and how we can fix it. Massachusetts, USA: Harvard University Press.

Chishtie, F. (2012). Phronesis and the practice of science. In E. A. Kinsella, \& A. Pitman. (Eds.), Phronesis as professional knowledge: Practical wisdom in the professions. Rotterdam, Netherlands: Sense Publishers.

Creswell, J. W. (2013). Qualitative inquiry and research design: Choosing among five approaches (3rd ed.). London, UK: Sage.

Cummings, S., \& Tsoukas, H. (1997). Marginalization and recovery: The emergence of Aristotelian themes in organization studies. Organization Studies, 18(4), 665-683.

Czarniawska, B. (2015). After practice: A personal reflection. Nordic Journal of Working Life Studies, 5(3), 105-114. doi: http://dx.doi. org/10.19154/njwls.v5iza.4836

Czarniawska, B. (2016). Reflexivity versus rigor. Management Learning, ahead of print, 1-5. doi: 10.1177/1350507616663436

Dent, E. B. (2002). Developing scholarly practitioners: Doctoral management education in the 21st century. In C. Wankel, \& R. Defillipi (Eds.), Rethinking management education: For the 21st century (pp. 135-155). Greenwich, UK: Information Age Press.

Freire, P. (1970). Pedagogy of the oppressed. New York, USA: Herder and Herder.

French, R., \& Grey, C. (Eds.) (1996). Rethinking management education. London, UK: Sage.

Griffiths, J., \& Mack, K. (2011). Senses of "shipscapes": An artful navigation of ship architecture and aesthetics. Journal of Organizational Change Management, 24(6), 733-750. doi: 10.1108/09534811111175724

Khurana, R., \& Spender, J. C. (2012). J. C. Herbert A. Simon on what ails business schools: More than a problem in organizational design. Journal of Management Studies, 49(3), 1-21. doi: 10.1111/j.14676486.2011.01040.x

Kinsella, E. A. (2012). Practitioner reflection and judgement as phronesis: A continuum of reflection and considerations for phronetic judgement. In E. A. Kinsella, \& A. Pitman (Eds.), Phronesis as professional knowledge: Practical wisdom in the professions (pp. 35-52). Rotterdam, Netherlands: Sense Publishers.

Kinsella, E. A., \& Whiteford, G. (2009). Knowledge generation and utilization: Toward epistemic reflexivity. Australian Occupational Therapy Journal, 56(4), 249-258. doi: 10.1111/j.1440-1630.2007.00726.x

Kuhn, T. (1996 [1962]). The structure of scientific revolutions. Chicago, USA: The University of Chicago Press.

Macklin, R., \& Whiteford, G. (2012). Phronesis, aporia, and qualitative research. In E. A. Kinsella, \& A. Pitman (Eds.), Phronesis as professional knowledge: Practical wisdom in the professions (pp. 87-100). Rotterdam, Netherlands: Sense Publishers.

Marx, R. D., Garcia, J. E., Butterfield, D. A., Kappen, J. A., \& Baldwin, T. T. . (2015). Isn't it time we did something about the lack of teaching preparation in business doctoral programs? Journal of Management Education, ahead of print. doi: 10.1177/1052562915616430. 
Merleau-Ponty, M. (2004). The world of perception. New York, USA: Routledge.

Mowbray, S., \& Halse, C. (2010). The purpose of the PhD: Theorising the skills acquired by students. Higher Education Research and Development, 29(6), 653-664. doi: dx.doi.org/10.1080/07294360.201 0.487199

Pakaluk, M. (2005). Aristotles's nicomachean ethics: An introduction. Massachusetts, USA: Cambridge University Press.

Schatzki, T. (2001). Introduction: Practice theory. In T. Schatzki, K. Knorr Cetina, \& E. von Savigny (Eds.), The practice turn in contemporary theory (pp. 1-14). New York, USA: Routledge.

Schatzki, T. (2012). A primer on practices. In Higgs, J. et al. (Eds.), Practice-based education: Perspectives and strategies (pp. 13-26). Rotterdam, Netherlands: Sense Publishers.

Schön, D. (1987). Educating the reflective practitioner. San Francisco, USA: Jossey-Bass.

Shotter, J., \& Tsoukas, H. (2014). Performing phronesis: On the way to engaged judgement. Management Learning, 45(4), 377-396. doi: $10.1177 / 1350507614541196$

Stake, R. E. (2010). Qualitative research: Studying how things work. New York, USA: Guilford.
Strati, A. (1992). Aesthetic understanding of organizational life. Academy of Management Review, 17(3), 568-581.

Strati, A. (2007). Sensible knowledge and practice-based learning. Management Learning, 38(1), 61-77. doi: 10.1177/1350507607073023

Sutherland, I. (2012). Arts-based methods in leadership development: Affording aesthetic workplaces, reflexivity and memories with momentum. Management Learning, 44(1), 25-43. doi: $10.1177 / 1350507612465063$

Thomas, A. B., \& Anthony, P. D. (1996). Can management education be educational? In R. French, \& C. Grey (Eds.), Rethinking management education (pp. 17-35). London, UK: Sage.

Vaara, E., \& Fay, E. (2012). Reproduction and change on the global scale: A Bourdieusian perspective on management education. Journal of Management Studies, 49(6), 1023-1051. doi: 10.1111/j.14676486.2012.01049.x

Vico, G. (1725). Principi di una scienza nuova. Napoli, Italia Mosca.

Warren, S. (2008). Empirical challenges in organizational aesthetics research: Towards a sensual methodology. Organization Studies, 29(4), 559-580. doi: 10.1177/0170840607083104 